\title{
Inhibition of Erythrocyte Cell Membrane Scrambling Following Energy Depletion and Hyperosmotic Shock by Alectinib
}

\author{
Abdulla Al Mamun Bhuyan ${ }^{a}$ Florian Langa,b \\ aDepartment of Vegetative and Clinical Physiology, Eberhard-Karls-University of Tuebingen, Tuebingen, \\ bDepartment of Molecular Medicine II, Medical Faculty, Heinrich Heine University, Düsseldorf, Germany
}

\section{Key Words}

Phosphatidylserine - Eryptosis - Alectinib - Glucose deprivation - Hyperosmolarity • Oxidative stress $\bullet$ Ionomycin $\bullet$ Calcium

\begin{abstract}
Background/Aims: The anaplastic lymphoma kinase (ALK) inhibitor alectinib is clinically used for the treatment of ALK positive non-small-cell lung cancer. At least in part the substance is effective by triggering suicidal death or apoptosis of tumor cells. Erythrocytes are lacking mitochondria and nuclei, key organelles of apoptosis but are, similar to apoptosis of nucleated cells, able to enter suicidal erythrocyte death or eryptosis. Stimulators of eryptosis include energy depletion, hyperosmotic shock, oxidative stress, and increase of cytosolic $\mathrm{Ca}^{2+}$ activity $\left(\left[\mathrm{Ca}^{2+}\right]_{\mathrm{i}}\right)$. The present study explored, whether alectinib influences eryptosis. Methods: Flow cytometry was employed to quantify phosphatidylserine exposure at the cell surface from annexin-V-binding and cell volume from forward scatter. Measurements were made without or with energy depletion (glucose deprivation for 48 hours), hyperosmotic shock $(+550 \mathrm{mM}$ sucrose for 6 hours), oxidative stress (50 min exposure to $0.3 \mathrm{mM}$ tert-butylhydroperoxide), and $\mathrm{Ca}^{2+}$ loading (60 minutes treatment with $1 \mu \mathrm{M} \mathrm{Ca}{ }^{2+}$ ionophore ionomycin). Results: $\mathrm{A}$ 48 hours exposure of human erythrocytes to alectinib $(150-600 \mathrm{ng} / \mathrm{ml})$ did not significantly modify the percentage of annexin- $V$-binding cells and forward scatter. Energy depletion, hyperosmotic shock, oxidative stress and $\mathrm{Ca}^{2+}$ loading were each followed by profound and significant increase of the percentage annexin- $\mathrm{V}$-binding erythrocytes and a significant decrease of forward scatter. The effects of energy depletion and hyperosmotic shock, but not of oxidative stress or $\mathrm{Ca}^{2+}$ loading on annexin-V-binding were significantly blunted in the presence of alectinib $(150-600 \mathrm{ng} / \mathrm{ml})$. In none of the conditions was forward scatter significantly modified by alectinib. Conclusion: Alectinib inhibits cell membrane scrambling following energy depletion and hyperosmotic shock.




\section{Introduction}

The Anaplastic lymphoma kinase (ALK) inhibitor [1-3] Alectinib is used for the treatment of ALK positive non-small-cell lung cancer (NSCLC) [1-20]. Alectinib is at least in part effective by triggering suicidal death or apoptosis of tumor cells [21,22].

Even though lacking mitochondria and nuclei, erythrocytes may similarly enter suicidal death or eryptosis, which is characterized by cell membrane scrambling with phosphatidylserine translocation to the cell surface [23-25]. Typically eryptosis is paralleled by cell shrinkage [26]. Eryptosis could be triggered by energy depletion, hyperosmotic shock, and oxidative stress [25]. Moreover, eryptosis is stimulated by a myriad of small chemicals and diverse clinical conditions [27-127]. The cellular machinery orchestrating eryptosis includes increase of cytosolic $\mathrm{Ca}^{2+}$ activity $\left(\left[\mathrm{Ca}^{2+}\right]_{\mathrm{i}}\right)[25]$, ceramide [128], G-protein Galphai2 [89], and activation of diverse kinases including casein kinase $1 \alpha$, Janus-activated kinase JAK3, protein kinase $C$, and p38 kinase [25]. Eryptosis is inhibited by several kinases including AMP activated kinase AMPK, cGMP-dependent protein kinase, PAK2 kinase, and mitogen and stress activated kinase MSK1/2 [129].

The present study was designed to test, whether alectinib is able to trigger eryptosis. Surprisingly, the substance turned out to inhibit eryptosis. Thus, the effect of alectinib on eryptosis following energy depletion, hyperosmotic shock, oxidative stress and cellular $\mathrm{Ca}^{2+}$ load was quantified. Accordingly, human erythrocytes from healthy volunteers were exposed to glucose deprivation, hypertonic extracellular osmolarity, the oxidant tert-butylhydroperoxide or the $\mathrm{Ca}^{2+}$ ionophore ionomycin, and phosphatidylserine surface abundance as well as cell volume determined by flow cytometry.

\section{Materials and Methods}

\section{Erythrocytes, solutions and chemicals}

Fresh Li-Heparin-anticoagulated blood samples were kindly provided by the blood bank of the University of Tübingen. The study is approved by the ethics committee of the University of Tübingen (184/2003 V). The blood was centrifuged at $120 \mathrm{~g}$ for $20 \mathrm{~min}$ at $21^{\circ} \mathrm{C}$ and the platelets and leukocytes-containing supernatant was disposed. Erythrocytes were incubated in vitro at a hematocrit of $0.4 \%$ in Ringer solution containing (in $\mathrm{mM}$ ) $125 \mathrm{NaCl}, 5 \mathrm{KCl}, 1 \mathrm{MgSO}_{4}$, $32 \mathrm{~N}$-2-hydroxyethylpiperazine-N-2-ethanesulfonic acid (HEPES; pH 7.4), 5 glucose, $1 \mathrm{CaCl}_{2}$, at $37^{\circ} \mathrm{C}$ for 48 hours. Where indicated, erythrocytes were exposed for 48 hours to glucose containing or glucose depleted Ringer solution, for 6 hours to hyperosmotic extracellular fluid (550 mM sucrose added), for 50 minutes to the oxidant tert-butyl-hydroperoxide ( $0.3 \mathrm{mM}$, Sigma Aldrich, Hamburg, Germany), or for 60 minutes to $\mathrm{Ca}^{2+}$ ionophore ionomycin ( $1 \mu \mathrm{M}$, Merck Millipore, Darmstadt, Germany), each in the absence and presence of alectinib (150-600 ng/ml, MedChem Express, Princeton, USA).

\section{Annexin-V-binding, forward scatter}

After incubation under the respective experimental condition, a $150 \mu \mathrm{l}$ cell suspension was washed in Ringer solution containing $5 \mathrm{mM} \mathrm{CaCl}_{2}$ and then stained with Annexin-V-FITC (1:200 dilution; ImmunoTools, Friesoythe, Germany) in this solution at $37^{\circ} \mathrm{C}$ for $15 \mathrm{~min}$ under protection from light. The annexin-Vabundance at the erythrocyte surface was subsequently determined on a FACS Calibur (BD, Heidelberg, Germany). Annexin-V-binding was measured with an excitation wavelength of $488 \mathrm{~nm}$ and an emission wavelength of $530 \mathrm{~nm}$. A marker (M1) was placed to set an arbitrary threshold between annexin-V-binding cells and control cells. The same threshold was used for untreated and alectinib treated erythrocytes. A dot plot of forward scatter (FSC) vs. side scatter (SSC) was set to linear scale for both parameters. The threshold of forward scatter was set at the default value of " 52 ".

\section{Statistics}

Data are expressed as arithmetic means \pm SEM. As indicated in the figure legends, statistical analysis was made using ANOVA with Tukey's test as post-test and $t$ test as appropriate. $\mathrm{n}$ denotes the number of different erythrocyte specimens studied. Since different erythrocyte specimens used in distinct experiments are differently susceptible to triggers of eryptosis, the same erythrocyte specimens have been used for control and experimental conditions. 
Results

The present study explored, whether alectinib influences eryptosis, the suicidal erythrocyte death. The two hallmarks of eryptosis, i.e. cell shrinkage and phospholipid scrambling of the cell membrane with phosphatidylserine translocation to the cell surface were determined by flow cytometry. Phosphatidylserin e exposing erythrocytes were identified utilizing annexin-V-binding to phosphatidylserine, cell shrinkage was quantified utilizing forward scatter.

In a first series of experiments erythrocytes were incubated for 48 hours in the absence of glucose in order to induce energy depletion. As shown in Fig. 1 , a 48 hours exposure to glucose depleted Ringer solution was followed by a marked increase of the percentage of annexin-Vbinding erythrocytes. The addition of alectinib (150$600 \mathrm{ng} / \mathrm{ml}$ ) significantly blunted the increase of the percentage of annexinV-binding erythrocytes following energy depletion. However, even in the presence of alectinib, energy depletion significantly increased the percentage of phosphatidylserine exposing erythrocytes (Fig. 1).

Exposure of the erythrocytes to energy depletion was further

followed by a significant decrease of forward scatter (Fig. 2). The effect on forward scatter was not significantly modified by alectinib $(150-600 \mathrm{ng} / \mathrm{ml})$.

In a second series of experiments erythrocytes were exposed for 6 hours to isotonic or hypertonic $(+550 \mathrm{mM}$ sucrose) extracellular fluid. As shown in Fig. 3, a 6 hours

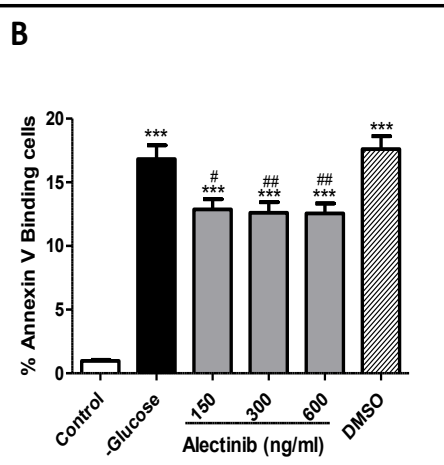

Fig. 1. Alectinib sensitivity of phosphatidylserine exposure following energy depletion A. Original histograms of annexin-V-binding of erythrocytes following exposure for 48 hours to glucose containing Ringer solution (grey area), Ringer solution without glucose (black line) and Ringer solution without glucose in the presence of alectinib $(600 \mathrm{ng} / \mathrm{ml})$ (red line). B. Arithmetic means \pm SEM $(\mathrm{n}=18)$ of the percentage annexin-V-binding erythrocytes after a 48 hours treatment with Ringer solution with (white bar, control) or without (black and grey bars) glucose in the absence (black bar) and presence of 150$600 \mathrm{ng} / \mathrm{ml}$ alectinib (grey bars) or of solvent alone (Striped bar). $* * *(p<0.001)$ indicates significant difference from the presence of glucose, $\#(p<0.05), \# \#(p<0.01)$ indicates significant difference from the absence of alectinib (ANOVA).

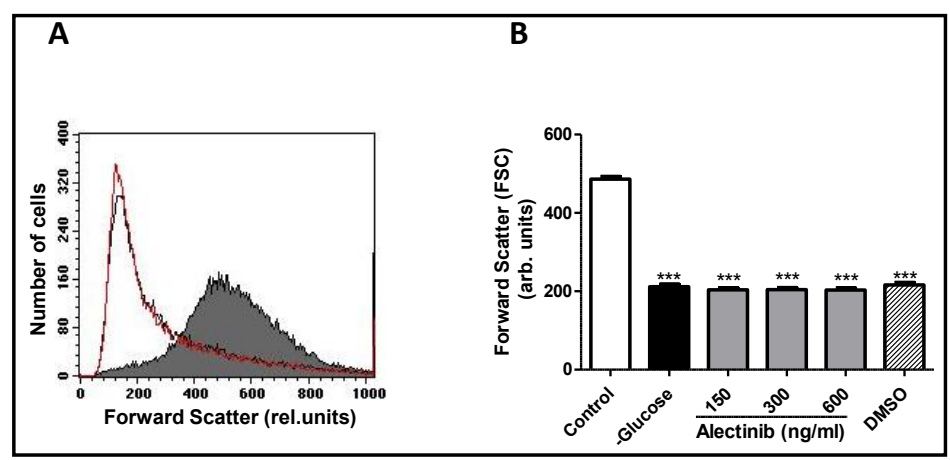

Fig. 2. Alectinib sensitivity of cell shrinkage following energy depletion. A. Original histograms of erythrocyte forward scatter following exposure for 48 hours to glucose containing Ringer solution (grey area), Ringer solution without glucose (black line) and Ringer solution without glucose in the presence of alectinib $(600 \mathrm{ng} / \mathrm{ml}$ ) (red line). B. Arithmetic means \pm SEM $(n=15)$ of the erythrocyte forward scatter after a 48 hours treatment with Ringer solution with (white bar, control) or without (black and grey bars) glucose in the absence (black bar) and presence of 150-600 ng/ml alectinib (grey bars) or of solvent alone (Striped bar). ${ }^{* * *}(\mathrm{p}<0.001)$ indicates significant difference from the presence of glucose. 
exposure to hyperosmotic shock was followed by a marked increase of the percentage of annexin-Vbinding erythrocytes. The addition of alectinib (150$600 \mathrm{ng} / \mathrm{ml}$ ) significantly blunted the increase of the percentage of annexinV-binding erythrocytes following hyperosmotic shock. However, even in the presence of alectinib, hyperosmotic shock significantly increased the percentage of phosphatidylserine exposing erythrocytes (Fig. $3)$.

the exposure $\quad$ of hyperosmotic shock for 6 hours was further followed by a significant decrease of forward scatter (Fig. 4). The effect on forward scatter was not significantly modified by alectinib (150$600 \mathrm{ng} / \mathrm{ml}$ ).

In order to induce oxidative stress, erythrocytes were exposed for 50 minutes to $0.3 \mathrm{mM}$ tert-butyl-hydroperoxide. As illustrated in Fig. 5, oxidative stress was followed by a sharp increase of the percentage of annexin-V-binding erythrocytes. The effect was not appreciably modified by alectinib (Fig. 5).

Exposure of the erythrocytes for 50 minutes to $0.3 \mathrm{mM}$ tert-butylhydroperoxide was further followed by a significant decrease of forward scatter (Fig. 6). The effect was again not significantly modified by alectinib (150-600 ng/ $\mathrm{ml}$ ).

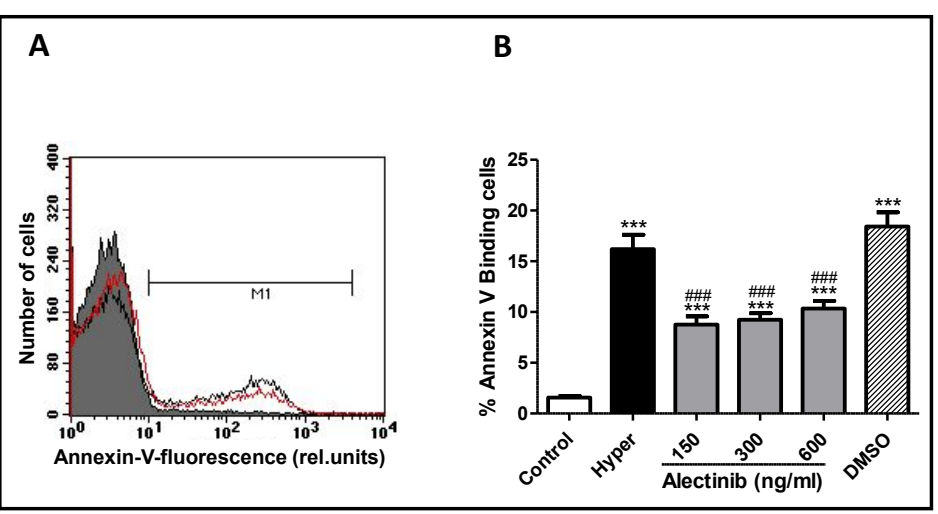

Fig. 3. Alectinib sensitivity of phosphatidylserine exposure following hyperosmotic shock. A. Original histograms of annexin-V-binding of erythrocytes following exposure for 6 hours to isosmotic Ringer solution (grey area), hyperosmotic Ringer (550 mM sucrose added) (black line) and hyperosmotic Ringer in the presence of alectinib (600 $\mathrm{ng} / \mathrm{ml}$ ) (red line). B. Arithmetic means \pm SEM $(\mathrm{n}=15)$ of the percentage annexin-V-binding erythrocytes after a 6 hours treatment with isotonic Ringer solution (white bar, control) or with hyperosmotic $550 \mathrm{mM}$ sucrose added) Ringer (black and grey bars) in the absence (black bar) and presence of 150-600 ng/ml alectinib (light grey bars) or of solvent alone (Striped bar). ${ }^{* * *}(\mathrm{p}<0.001)$ indicates significant difference from the presence of isotonic Ringer, \#\#\#(p<0.001) indicates significant difference from the absence of alectinib (ANOVA).

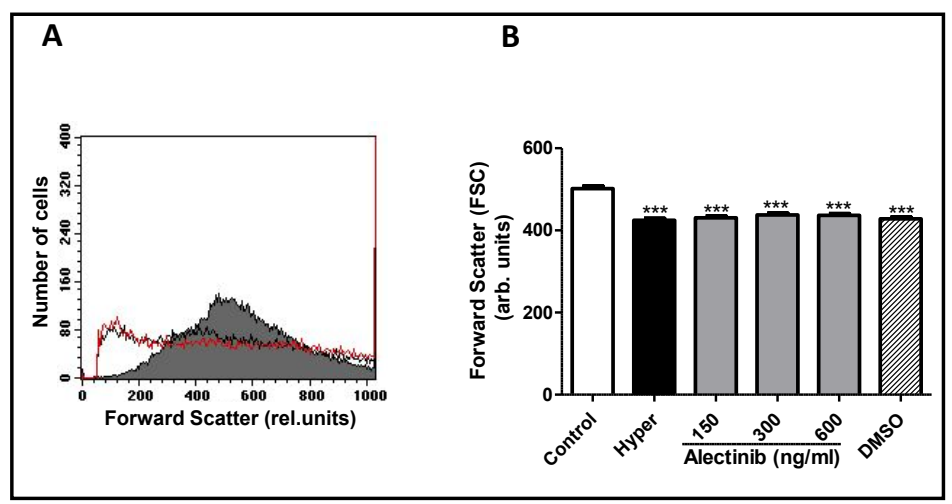

Fig. 4. Alectinib sensitivity of cell shrinkage following hyperosmotic shock. A. Original histograms of erythrocyte forward scatter following exposure for 6 hours to glucose containing isosmotic Ringer solution (grey area), hyperosmotic Ringer (550 mM sucrose added) (black line) and hyperosmotic Ringer in the presence of alectinib (600 ng/ $\mathrm{ml}$ ) (red line). B. Arithmetic means \pm SEM $(n=15)$ of the erythrocyte forward scatter after a 6 hours treatment with isotonic Ringer solution (white bar, control) or with hyperosmotic (550 mM sucrose added) Ringer (black and grey bars) in the absence (black bar) and presence of $150-600 \mathrm{ng} / \mathrm{ml}$ alectinib (light grey bars) or of solvent alone (Striped bar). ${ }^{* * *}(\mathrm{p}<0.001)$ indicates significant difference from the presence of isotonic Ringer. 
Fig. 5. Alectinib sensitivity of phosphatidylserine exposure following oxidative stress. A. Original histograms of annexin-Vbinding of erythrocytes following exposure for $50 \mathrm{~min}$ to glucose containing Ringer solution without (grey area) or with $0.3 \mathrm{mM}$ tertbutyl-hydroperoxide (t-BOOH) added (black and red lines) without (black line) and with (red line) presence of alectinib (600 $\mathrm{ng} /$

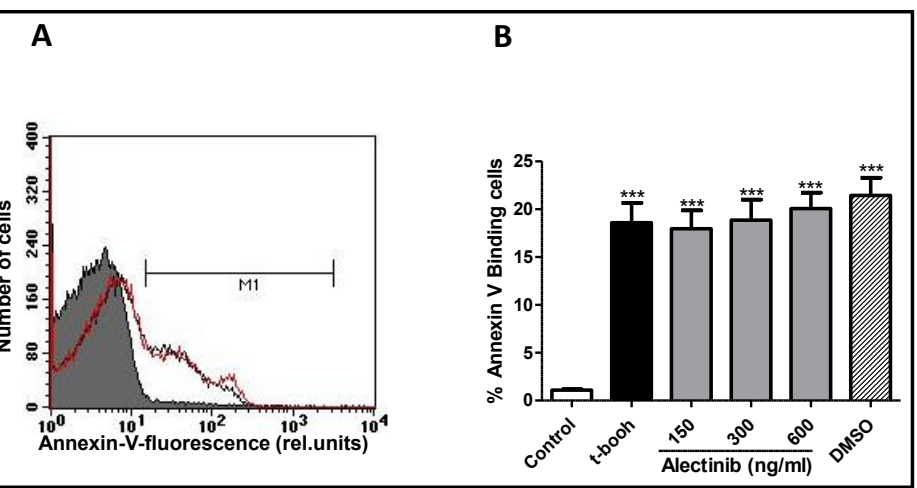
$\mathrm{ml}$ ). B. Arithmetic means \pm SEM (n $=5$ ) of the percentage annexin-V-binding erythrocytes after 50 min treatment with Ringer solution without (white bar, control) or with (black and grey bars) $0.3 \mathrm{mM}$ tert-butyl-hydroperoxide (t-BOOH) added in the absence (black bar) and presence of 150-600 ng/ml alectinib (light grey bars) or of solvent alone (Striped bar). ${ }^{* * *}(\mathrm{p}<0.001)$ indicates significant difference from the abscence of $0.3 \mathrm{mM}$ tert-butyl-hydroperoxide (t-BOOH) (ANOVA).

Fig. 6. Alectinib sensitivity of cell shrinkage following oxidative stress. A. Original histograms of erythrocyte forward scatter following exposure for $50 \mathrm{~min}$ to glucose containing Ringer solution without (grey area) or with 0.3 $\mathrm{mM} \quad$ tert-butyl-hydroperoxide (t-BOOH) added (black and red lines) without (black line) and with (red line) presence of alectinib

A

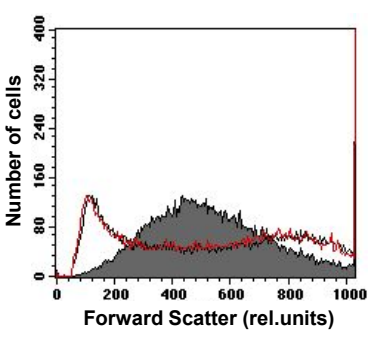

B

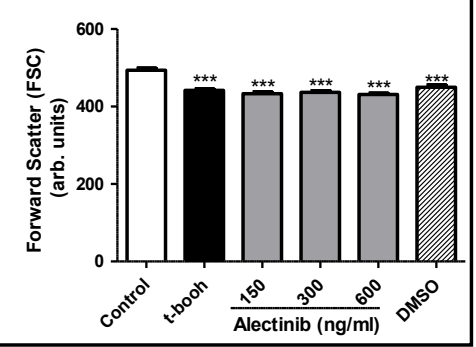
$(600 \mathrm{ng} / \mathrm{ml})$. B. Arithmetic means \pm SEM $(n=5)$ of the erythrocyte forward scatter after a 50 min treatment with Ringer solution without (white bar, control) or with (black and grey bars) $0.3 \mathrm{mM}$ tert-butyl-hydroperoxide (t-BOOH) added in the absence (black bar) and presence of $150-600 \mathrm{ng} / \mathrm{ml}$ alectinib (light grey bars) or of solvent alone (Striped bar). ${ }^{* * *}(\mathrm{p}<0.001)$ indicates significant difference from the abscence of $0.3 \mathrm{mM}$ tert-butyl-hydroperoxide ( $\mathrm{t}-\mathrm{BOOH}$ ) (ANOVA).

Exposure of the erythrocytes for 60 minutes to $1 \mu \mathrm{M}$ ionomycin was followed by a sharp increase of the percentage of annexin-V-binding erythrocytes (Fig. 7). The effect was not significantly modified by alectinib (150-600 $\mathrm{ng} / \mathrm{ml}$ alectinib).

Exposure of the erythrocytes for 60 minutes to $1 \mu \mathrm{M}$ ionomycin was further followed by a sharp decrease of forward scatter (Fig. 8), an effect again not significantly modified by the presence of alectinib $(150-600 \mathrm{ng} / \mathrm{ml})$. 
Fig. 7. Alectinib sensitivity of phosphatidylserine exposure following $\mathrm{Ca}^{2+}$ overload. A. Original histograms of annexin-V-binding of erythrocytes following exposure for $60 \mathrm{~min}$ to glucose containing Ringer solution without (grey area) or with $1.0 \mu \mathrm{M}$ ionomycin added (black and red lines) without (black line) and with (red line) presence of alectinib (600 $\mathrm{ng} / \mathrm{ml}$ ). B. Arithmetic means \pm SEM $(n=15)$ of the percentage annexin-

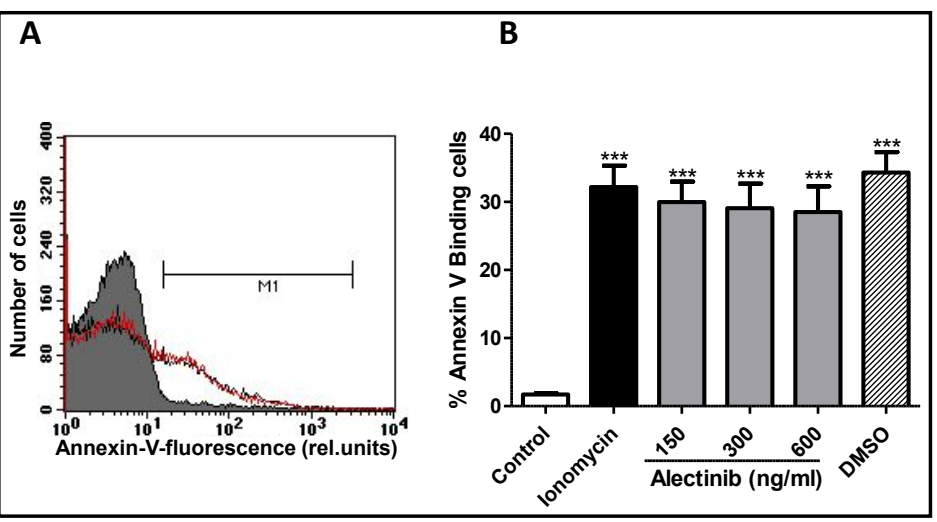
V-binding erythrocytes after a 60 min treatment with Ringer solution without (white bar, control) or with (black and grey bars) $1.0 \mu \mathrm{M}$ ionomycin added in the absence (black bar) and presence of 150-600 ng/ml alectinib (light grey bars) or of solvent alone (Striped bar). ${ }^{* * *}(\mathrm{p}<0.001)$ indicates significant difference from the absence of Ionomycin (ANOVA).

Fig. 8. Alectinib sensitivity of cell shrinkage following $\mathrm{Ca}^{2+}$ overload. A. Original histograms of erythrocyte forward scatter following exposure for $60 \mathrm{~min}$ to glucose containing Ringer solution without (grey area) or with $1.0 \mu \mathrm{M}$ ionomycin added (black and red lines) without (black line) and with (red line) presence of alectinib (600 ng/ml). B. Arithmetic means \pm SEM $(n=15)$ of the erythrocyte

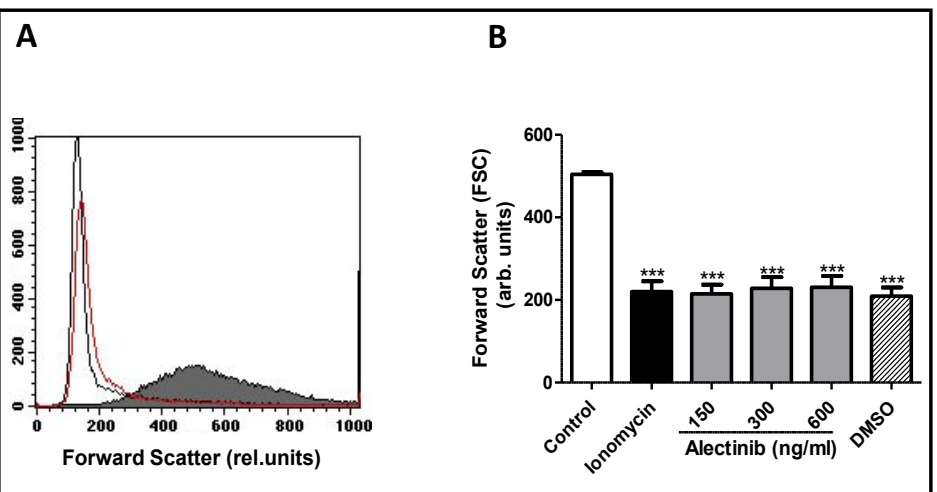
forward scatter after a $60 \mathrm{~min}$ treatment with Ringer solution without (white bar, control) or with (black and grey bars) $1.0 \mu \mathrm{M}$ ionomycin added in the absence (black bar) and presence of 150-600 ng/ml alectinib (light grey bars) or of solvent alone (Striped bar). ${ }^{* *}(\mathrm{p}<0.001)$ indicates significant difference from the absence of Ionomycin, (ANOVA).

\section{Discussion}

The present observations disclose the unexpected inhibitory effect of alectinib on eryptosis, the suicidal erythrocyte death characterized by cell shrinkage and cell membrane scrambling with phosphatidylserine translocation to the erythrocyte surface [25].

Alectinib itself did not appreciably modify the percentage of phosphatidylserine exposing erythrocytes. Similar to earlier observations [25], cell membrane scrambling and cell shrinkage were observed following energy depletion, hyperosmotic shock, oxidative stress and $\mathrm{Ca}^{2+}$ loading. Alectinib did not significantly modify the effect of oxidative stress and $\mathrm{Ca}^{2+}$ loading on cell membrane scrambling, but significantly blunted the cell membrane scrambling following energy depletion and hyperosmotic shock.

Under none of the conditions, Alectinib significantly modified the forward scatter. Under most conditions leading to eryptosis, cell shrinkage is due to increase of cytosolic $\mathrm{Ca}^{2+}$ activity $\left(\left[\mathrm{Ca}^{2+}\right]_{\mathrm{i}}\right)$ with subsequent activation of $\mathrm{Ca}^{2+}$ sensitive $\mathrm{K}^{+}$channels, $\mathrm{K}^{+}$exit, cell membrane hyperpolarization, $\mathrm{Cl}^{-}$exit and thus cellular loss of $\mathrm{KCl}$ with water. Apparently, Alectinib fails to significantly interfere with those mechanisms. 
Inhibition of eryptosis may be desirable in diverse clinical conditions associated with enhanced eryptosis including iron deficiency [25], dehydration [130], hyperphosphatemia [131], vitamin D excess [132], chronic kidney disease (CKD) [81, 133-137], hemolyticuremic syndrome [138], diabetes [139], hepatic failure [111, 140], malignancy $[25,108$, 141], sepsis [142], sickle-cell disease [25], beta-thalassemia [25], Hb-C and G6PD-deficiency [25], as well as Wilson's disease [142]. The rapid clearance of the phosphatidylserine exposing erythrocytes from circulating blood [25] may lead to anemia as soon as the loss of erythrocytes outcasts the formation of new erythrocytes by erythropoiesis [25]. Phosphatidylserine exposing erythrocytes adhere to the vascular wall [143], stimulate blood clotting and trigger thrombosis [144-146]. Excessive eryptosis may thus interfere with microcirculation [128, 144, 147-150]. Inhibitors of eryptosis may counteract anemia and restore microcirculation in clinical conditions with enhanced eryptosis [25]. However, inhibition of eryptosis may prevent the clearance of defective erythrocytes from circulating blood leading to the risk that defective erythrocytes may undergo hemolysis [25] with release of hemoglobin which may pass the renal glomerular filter, precipitate in the acidic lumen of renal tubules, occlude nephrons and thus lead to renal failure [151]. Additional experimental effort is needed to decipher the benefits and risks of eryptosis prevention.

In conclusion, Alectinib interferes with cell membrane scrambling following energy depletion and hyperosmotic shock. The potential therapeutic implications of the present observations remain to be defined.

\section{Acknowledgements}

The authors acknowledge the meticulous preparation of the manuscript by Tanja Loch. The study was supported by the Deutsche Forschungsgemeinschaft and by the Open Access Publishing Fund, University of Tuebingen.

\section{Disclosure Statement}

No conflict of interests exists.

\section{References}

1 DiBonaventura MD, Wong W, Shah-Manek B, Schulz M: Real-world usage and clinical outcomes of alectinib among post-crizotinib progression anaplastic lymphoma kinase positive non-small-cell lung cancer patients in the USA. Onco Targets Ther 2018;11:75-82.

2 Ly AC, Olin JL, Smith MB: Alectinib for advanced ALK-positive non-small-cell lung cancer. Am J Health Syst Pharm 2018;75:515-522.

- Peters S, Camidge DR, Shaw AT, Gadgeel S, Ahn JS, Kim DW, Ou SI, Perol M, Dziadziuszko R, Rosell R, Zeaiter A, Mitry E, Golding S, Balas B, Noe J, Morcos PN, Mok T: Alectinib versus Crizotinib in Untreated ALKPositive Non-Small-Cell Lung Cancer. N Engl J Med 2017;377:829-838.

4 Avrillon V, Perol M: Alectinib for treatment of ALK-positive non-small-cell lung cancer. Future Oncol 2017;13:321-335.

5 Gadgeel SM, Shaw AT, Govindan R, Gandhi L, Socinski MA, Camidge DR, De Petris L, Kim DW, Chiappori A, Moro-Sibilot DL, Duruisseaux M, Crino L, De Pas T, Dansin E, Tessmer A, Yang JC, Han JY, Bordogna W, Golding S, Zeaiter A, Ou SI: Pooled Analysis of CNS Response to Alectinib in Two Studies of Pretreated Patients With ALK-Positive Non-Small-Cell Lung Cancer. J Clin Oncol 2016;34:4079-4085.

6 Gandhi L, Ou SI, Shaw AT, Barlesi F, Dingemans AC, Kim DW, Camidge DR, Hughes BGM, Yang JC, de Castro J, Crino L, Lena H, Do P, Golding S, Bordogna W, Zeaiter A, Kotb A, Gadgeel S: Efficacy of alectinib in central nervous system metastases in crizotinib-resistant ALK-positive non-small-cell lung cancer: Comparison of RECIST 1.1 and RANO-HGG criteria. Eur J Cancer 2017;82:27-33. 


\section{Cellular Physiology Cell Physiol Biochem 2018;51:1996-2009 \begin{tabular}{ll|l} 
and Biochemistry Published online: 6 December 2018 & $\begin{array}{l}\odot 2018 \text { The Author(s). Published by S. Karger AG, Basel } \\
\text { www.karger.com/cpb }\end{array}$ \\
\hline
\end{tabular}

7 Hida T, Nokihara H, Kondo M, Kim YH, Azuma K, Seto T, Takiguchi Y, Nishio M, Yoshioka H, Imamura F, Hotta K, Watanabe S, Goto K, Satouchi M, Kozuki T, Shukuya T, Nakagawa K, Mitsudomi T, Yamamoto N, Asakawa T, Asabe R, Tanaka T, Tamura T: Alectinib versus crizotinib in patients with ALK-positive non-small-cell lung cancer (J-ALEX): an open-label, randomised phase 3 trial. Lancet 2017;390:29-39.

-8 Larkins E, Blumenthal GM, Chen H, He K, Agarwal R, Gieser G, Stephens O, Zahalka E, Ringgold K, Helms W, Shord S, Yu J, Zhao H, Davis G, McKee AE, Keegan P, Pazdur R: FDA Approval: Alectinib for the Treatment of Metastatic, ALK-Positive Non-Small Cell Lung Cancer Following Crizotinib. Clin Cancer Res 2016;22:51715176.

-9 Mamesaya N, Nakashima K, Naito T, Nakajima T, Endo M, Takahashi T: ALK-rearranged lung squamous cell carcinoma responding to alectinib: a case report and review of the literature. BMC Cancer 2017;17:471.

10 Muller IB, de Langen AJ, Giovannetti E, Peters GJ: Anaplastic lymphoma kinase inhibition in metastatic nonsmall cell lung cancer: clinical impact of alectinib. Onco Targets Ther 2017;10:4535-4541.

-11 Ou SH, Ahn JS, De Petris L, Govindan R, Yang JC, Hughes B, Lena H, Moro-Sibilot D, Bearz A, Ramirez SV, Mekhail T, Spira A, Bordogna W, Balas B, Morcos PN, Monnet A, Zeaiter A, Kim DW: Alectinib in CrizotinibRefractory ALK-Rearranged Non-Small-Cell Lung Cancer: A Phase II Global Study. J Clin Oncol 2016;34:661668.

12 Rossi A: Alectinib for ALK-positive non-small-cell lung cancer. Expert Rev Clin Pharmacol 2016;9:10051013.

13 Shaw AT, Gandhi L, Gadgeel S, Riely GJ, Cetnar J, West H, Camidge DR, Socinski MA, Chiappori A, Mekhail T, Chao BH, Borghaei H, Gold KA, Zeaiter A, Bordogna W, Balas B, Puig O, Henschel V, Ou SI: Alectinib in ALKpositive, crizotinib-resistant, non-small-cell lung cancer: a single-group, multicentre, phase 2 trial. Lancet Oncol 2016;17:234-242.

14 Skoulidis F, Papadimitrakopoulou VA: Personalized Medicine Tackles Clinical Resistance: Alectinib in ALK-Positive Non-Small Cell Lung Cancer Progressing on First-Generation ALK Inhibitor. Clin Cancer Res 2016;22:5177-5182.

15 Srinivasamaharaj S, Salame BK, Rios-Perez J, Kloecker G, Perez CA: The role of alectinib in the treatment of advanced ALK-rearranged non-small-cell lung cancer. Expert Rev Anticancer Ther 2016;16:1227-1233.

16 Tran PN, Klempner SJ: Focus on Alectinib and Competitor Compounds for Second-Line Therapy in ALKRearranged NSCLC. Front Med (Lausanne) 2016;3:65.

17 Watanabe S, Hayashi H, Okamoto K, Fujiwara K, Hasegawa Y, Kaneda H, Tanaka K, Takeda M, Nakagawa K: Progression-Free and Overall Survival of Patients With ALK Rearrangement-Positive Non-Small Cell Lung Cancer Treated Sequentially With Crizotinib and Alectinib. Clin Lung Cancer 2016;17:528-534.

18 Yang JC, Ou SI, De Petris L, Gadgeel S, Gandhi L, Kim DW, Barlesi F, Govindan R, Dingemans AC, Crino L, Lena H, Popat S, Ahn JS, Dansin E, Golding S, Bordogna W, Balas B, Morcos PN, Zeaiter A, Shaw AT: Pooled Systemic Efficacy and Safety Data from the Pivotal Phase II Studies (NP28673 and NP28761) of Alectinib in ALK-positive Non-Small Cell Lung Cancer. J Thorac Oncol 2017;12:1552-1560.

19 Yoshida T, Hida T, Yatabe Y: Rapid and dramatic response to alectinib in an anaplastic lymphoma kinase rearranged non-small-cell lung cancer patient who is critically ill. Anticancer Drugs 2016;27:573-575.

-20 Zhu V, Ou SH: Safety of alectinib for the treatment of metastatic ALK-rearranged non-small cell lung cancer. Expert Opin Drug Saf 2017;16:509-514.

21 Arai S, Kita K, Tanimoto A, Takeuchi S, Fukuda K, Sato H, Yano S: In vitro and in vivo anti-tumor activity of alectinib in tumor cells with NCOA4-RET. Oncotarget 2017;8:73766-73773.

-22 Lu J, Guan S, Zhao Y, Yu Y, Woodfield SE, Zhang H, Yang KL, Bieerkehazhi S, Qi L, Li X, Gu J, Xu X, Jin J, Muscal JA, Yang T, Xu GT, Yang J: The second-generation ALK inhibitor alectinib effectively induces apoptosis in human neuroblastoma cells and inhibits tumor growth in a TH-MYCN transgenic neuroblastoma mouse model. Cancer Lett 2017;400:61-68.

-23 Lau IP, Chen H, Wang J, Ong HC, Leung KC, Ho HP, Kong SK: In vitro effect of CTAB- and PEG-coated gold nanorods on the induction of eryptosis/erythroptosis in human erythrocytes. Nanotoxicology 2012;6:847856.

24 Maellaro E, Leoncini S, Moretti D, Del Bello B, Tanganelli I, De Felice C, Ciccoli L: Erythrocyte caspase-3 activation and oxidative imbalance in erythrocytes and in plasma of type 2 diabetic patients. Acta Diabetol 2013;50:489-495.

25 Lang E, Lang F: Mechanisms and pathophysiological significance of eryptosis, the suicidal erythrocyte death. Semin Cell Dev Biol 2015;39:35-42. 


\section{Cellular Physiology Cell Physiol Biochem 2018;51:1996-2009 \begin{tabular}{l|l|l} 
and Biochemistry & $\begin{array}{l}\text { DOI: 10.1159/000495777 } \\
\text { Published online: 6 December } 2018\end{array}$ & $\begin{array}{l}\text { @ 2018 The Author(s). Published by S. Karger AG, Basel } \\
\text { www.karger.com/cpb }\end{array}$ \\
\hline
\end{tabular}}

-26 Lang PA, Kaiser S, Myssina S, Wieder T, Lang F, Huber SM: Role of Ca2+-activated K+ channels in human erythrocyte apoptosis. Am J Physiol Cell Physiol 2003;285:C1553-C1560.

-27 Aliko V, Qirjo M, Sula E, Morina V, Faggio C: Antioxidant defense system, immune response and erythron profile modulation in gold fish, Carassius auratus, after acute manganese treatment. Fish Shellfish Immunol 2018;76:101-109.

28 Alvarez-Sala A, Lopez-Garcia G, Attanzio A, Tesoriere L, Cilla A, Barbera R, Alegria A: Effects of Plant Sterols or beta-Cryptoxanthin at Physiological Serum Concentrations on Suicidal Erythrocyte Death. J Agric Food Chem 2018;66:1157-1166.

29 Bester J, Matshailwe C, Pretorius E: Simultaneous presence of hypercoagulation and increased clot lysis time due to IL-1beta, IL-6 and IL-8. Cytokine 2018;10.1016/j.cyto.2018.01.007

30 Cao H, Umbach AT, Bissinger R, Gawaz M, Lang F: Inhibition of Collagen Related Peptide Induced Platelet Activation and Apoptosis by Ceritinib. Cell Physiol Biochem 2018;45:1707-1716.

-31 Kempe-Teufel DS, Bissinger R, Qadri SM, Wagner R, Peter A, Lang F: Cellular markers of eryptosis are altered in type 2 diabetes. Clin Chem Lab Med 2018;10.1515/cclm-2017-1058

-32 Liu C, Jiang P, Xu Y, Zheng M, Qiao J, Zhou X, Huang D, Bian M: Inhibition of Suicidal Erythrocyte Death by Indirubin-3'-Monoxime. Cell Physiol Biochem 2018;45:1108-1120.

-33 Nader E, Guillot N, Lavorel L, Hancco I, Fort R, Stauffer E, Renoux C, Joly P, Germain M, Connes P: Eryptosis and hemorheological responses to maximal exercise in athletes: Comparison between running and cycling. Scand J Med Sci Sports 2018;28:1532-1540.

-34 Qadri SM, Donkor DA, Nazy I, Branch DR, Sheffield WP: Bacterial neuraminidase-mediated erythrocyte desialylation provokes cell surface aminophospholipid exposure. Eur J Haematol 2018;100:502-510.

-35 Repsold L, Joubert AM: Eryptosis: An Erythrocyte's Suicidal Type of Cell Death. Biomed Res Int 2018;2018:9405617.

-36 Saising J, Nguyen MT, Hartner T, Ebner P, Al Mamun Bhuyan A, Berscheid A, Muehlenkamp M, Schakermann S, Kumari N, Maier ME, Voravuthikunchai SP, Bandow J, Lang F, Brotz-Oesterhelt H, Gotz F: Rhodomyrtone (Rom) is a membrane-active compound. Biochim Biophys Acta 2018;1860:1114-1124.

37 Al Mamun Bhuyan A, Ashiqul Haque AKM, Sahu I, Cao H, Kormann MSD, Lang F: Inhibition of Suicidal Erythrocyte Death by Volasertib. Cell Physiol Biochem 2017;43:1472-1486.

-38 Al Mamun Bhuyan A, Bissinger R, Cao H, Lang F: Inhibition of Erythrocyte Cell Membrane Scrambling by ASP3026. Cell Physiol Biochem 2017;43:507-517.

39 Al Mamun Bhuyan A, Nussle S, Cao H, Zhang S, Lang F: Simvastatin, a Novel Stimulator of Eryptosis, the Suicidal Erythrocyte Death. Cell Physiol Biochem 2017;43:492-506.

40 Bartolmas T, Mayer B, Balola AH, Salama A: Eryptosis in autoimmune haemolytic anaemia. Eur J Haematol 2018;100:36-44.

41 Farag MR, Alagawany M: Erythrocytes as a biological model for screening of xenobiotics toxicity. Chem Biol Interact 2018;279:73-83.

\$2 Jagadish S, Hemshekhar M, NaveenKumar SK, Sharath Kumar KS, Sundaram MS, Basappa, Girish KS, Rangappa KS: Novel oxolane derivative DMTD mitigates high glucose-induced erythrocyte apoptosis by regulating oxidative stress. Toxicol Appl Pharmacol 2017;334:167-179.

-43 Jemaa M, Fezai M, Bissinger R, Lang F: Methods Employed in Cytofluorometric Assessment of Eryptosis, the Suicidal Erythrocyte Death. Cell Physiol Biochem 2017;43:431-444.

44 Lang F, Bissinger R, Abed M, Artunc F: Eryptosis - the Neglected Cause of Anemia in End Stage Renal Disease. Kidney Blood Press Res 2017;42:749-760.

45 Totino PR, Lopes SC: Insights into the Cytoadherence Phenomenon of Plasmodium vivax: The Putative Role of Phosphatidylserine. Front Immunol 2017;8:1148.

46 Vu L, Ragupathy V, Kulkarni S, Atreya C: Analysis of Argonaute 2-microRNA complexes in ex vivo stored red blood cells. Transfusion 2017;57:2995-3000.

47 Al Mamun Bhuyan A, Cao H, Lang F: Triggering of Eryptosis, the Suicidal Erythrocyte Death by Mammalian Target of Rapamycin (mTOR) inhibitor Temsirolimus. Cell Physiol Biochem 2017;42:1575-1591.

48 Cao H, Bissinger R, Umbach AT, Gawaz M, Lang F: Effect of Bexarotene on Platelet Activation and Apoptosis. Cell Physiol Biochem 2017;42:838-847.

-49 Fallatah 0, Georges E: Apigenin-induced ABCC1-mediated efflux of glutathione from mature erythrocytes inhibits the proliferation of Plasmodium falciparum. Int J Antimicrob Agents 2017;50:673-677. 


\section{Cellular Physiology Cell Physiol Biochem 2018;51:1996-2009 \begin{tabular}{l|l|l} 
and Biochemistry Published onlIne: 6 December 2018 & $\begin{array}{l}\text { @ } 2018 \text { The Author(s). Published by S. Karger AG, Basel } \\
\text { www.karger.com/cpb }\end{array}$
\end{tabular}}

50 Ghashghaeinia M, Wesseling MC, Ramos E, Petkova-Kirova P, Waibel S, Lang E, Bissinger R, Alzoubi K, Edelmann B, Hosseinzadeh Z, Dreischer P, Shahvaroughi-Farahani A, Mrowietz U, Koberle M, Kaestner L, Bernhardt I, Martinez-Ruiz A, Wieder T, Lang F: Trifluoperazine-Induced Suicidal Erythrocyte Death and S-Nitrosylation Inhibition, Reversed by the Nitric Oxide Donor Sodium Nitroprusside. Cell Physiol Biochem 2017;42:1985-1998.

51 Lang E, Bissinger R, Qadri SM, Lang F: Suicidal death of erythrocytes in cancer and its chemotherapy: A potential target in the treatment of tumor-associated anemia. Int J Cancer 2017;141:1522-1528.

\$52 Meyring-Wosten A, Kuntsevich V, Campos I, Williams S, Ma J, Patel S, Ornillo C, Thijssen S, Kotanko P: Erythrocyte Sodium Sensitivity and Eryptosis in Chronic Hemodialysis Patients. Kidney Blood Press Res 2017;42:314-326.

53 Pinzon-Diaz CE, Calderon-Salinas JV, Rosas-Flores MM, Hernandez G, Lopez-Betancourt A, QuintanarEscorza MA: Eryptosis and oxidative damage in hypertensive and dyslipidemic patients. Mol Cell Biochem 2018;440:105-113.

54 Qadri SM, Bissinger R, Solh Z, Oldenborg PA: Eryptosis in health and disease: A paradigm shift towards understanding the (patho)physiological implications of programmed cell death of erythrocytes. Blood Rev 2017;31:349-361.

55 Ray RR: Adverse hematological effects of hexavalent chromium: an overview. Interdiscip Toxicol 2016;9:55-65.

56 Rodolfo B, Serafina P, Giuseppe B: Mechanisms Involved in the Increased Hemolysis in the Fetus and Newborn. Curr Pediatr Rev 2017;13:188-192.

57 Al Mamun Bhuyan A, Bissinger R, Cao H, Lang F: Triggering of Suicidal Erythrocyte Death by Exemestane. Cell Physiol Biochem 2017;42:1-12.

58 Al Mamun Bhuyan A, Wagner T, Cao H, Lang F: Triggering of Suicidal Erythrocyte Death by Gefitinib. Cell Physiol Biochem 2017;41:1697-1708.

59 Almasry M, Jemaa M, Mischitelli M, Lang F, Faggio C: Camalexin-Induced Cell Membrane Scrambling and Cell Shrinkage in Human Erythrocytes. Cell Physiol Biochem 2017;41:731-741.

60 Egler J, Lang F: Triggering of Eryptosis, the Suicidal Erythrocyte Death, by Perifosine. Cell Physiol Biochem 2017;41:2534-2544.

-61 Jemaa M, Fezai M, Lang F: Inhibition of Suicidal Erythrocyte Death by Reversine. Cell Physiol Biochem 2017;41:2363-2373.

62 Liu DH, Yao YT, Li LH, Huang CM: Effects of Ulinastatin on In vitro Storage Lesions of Human Red Blood Cells. Clin Lab 2017;63:833-838.

63 Qadri SM, Chen D, Schubert P, Devine DV, Sheffield WP: Early gamma-irradiation and subsequent storage of red cells in SAG-M additive solution potentiate energy imbalance, microvesiculation and susceptibility to stress-induced apoptotic cell death. Vox Sang 2017;112:480-483.

64 Rohrig G, Gutgemann I, von Gersdorff G, Polidori MC, Lupescu A, Lang F, Kolb G: [Current insights into anemia in old age : Summary of the symposium "Anemia in old age" on the occasion of the annual congress of the German Society for Geriatrics (DGG) 2016 in Stuttgart]. Z Gerontol Geriatr 2018;51:343-348.

-65 Swanepoel AC, Emmerson O, Pretorius E: Effect of Progesterone and Synthetic Progestins on Whole Blood Clot Formation and Erythrocyte Structure. Microsc Microanal 2017;23:607-617.

66 Swanepoel AC, Emmerson 0, Pretorius E: The Effect of Endogenous and Synthetic Estrogens on Whole Blood Clot Formation and Erythrocyte Structure. Microsc Microanal 2017;23:599-606.

67 Abed M, Alzoubi K, Lang F, Al Mamun Bhuayn A: Stimulation of Phospholipid Scrambling of the Erythrocyte Membrane by 9-Cis-Retinoic Acid. Cell Physiol Biochem 2017;41:543-554.

68 Abed M, Thiel C, Towhid ST, Alzoubi K, Honisch S, Lang F, Konigsrainer A: Stimulation of Erythrocyte Cell Membrane Scrambling by C-Reactive Protein. Cell Physiol Biochem 2017;41:806-818.

-69 Al Mamun Bhuyan A, Nguyen MT, Bissinger R, Gotz F, Lang F: Lipopeptide-Induced Suicidal Erythrocyte Death Correlates with the Degree of Acylation. Cell Physiol Biochem 2017;41:296-309.

70 Cao H, Bissinger R, Umbach AT, Al Mamun Bhuyan A, Lang F, Gawaz M: Effects of Antimalarial Tafenoquine on Blood Platelet Activity and Survival. Cell Physiol Biochem 2017;41:369-380.

-71 Fezai M, Slaymi C, Ben-Attia M, Lang F, Jemaa M: Purified Lesser weever fish venom (Trachinus vipera) induces eryptosis, apoptosis and cell cycle arrest. Sci Rep 2016;6:39288.

-72 Gusev GP, Govekar R, Gadewal N, Agalakova NI: Understanding quasi-apoptosis of the most numerous enucleated components of blood needs detailed molecular autopsy. Ageing Res Rev 2017;35:46-62. 


\section{Cellular Physiology Cell Physiol Biochem 2018;51:1996-2009

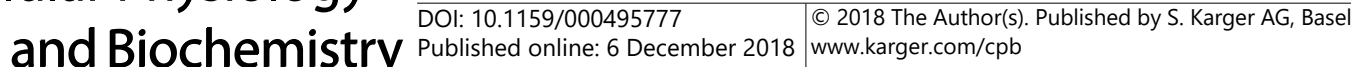

Bhuyan et al.: Inhibition of Eryptosis by Alectinib

73 Ibrahim UA, Yusuf AA, Ahmed SG: The Pathophysiologic Basis of Anaemia in Patients with Malignant Diseases. Gulf J Oncolog 2016;1:80-89.

74 Jiang P, Bian M, Ma W, Liu C, Yang P, Zhu B, Xu Y, Zheng M, Qiao J, Shuai Z, Zhou X, Huang D: Eryptosis as an Underlying Mechanism in Systemic Lupus Erythematosus-Related Anemia. Cell Physiol Biochem 2016;40:1391-1400.

75 Mischitelli M, Jemaaa M, Fezai M, Almasry M, Lang F, Faggio C: Stimulation of Erythrocyte Cell Membrane Scrambling by Adarotene. Cell Physiol Biochem 2017;41:519-529.

76 Qadri SM, Chen D, Schubert P, Perruzza DL, Bhakta V, Devine DV, Sheffield WP: Pathogen inactivation by riboflavin and ultraviolet light illumination accelerates the red blood cell storage lesion and promotes eryptosis. Transfusion 2017;57:661-673.

-77 Al Mamun Bhuyan A, Bissinger R, Cao H, Lang F: Triggering of Suicidal Erythrocyte Death by Bexarotene. Cell Physiol Biochem 2016;40:1239-1251.

-78 Al Mamun Bhuyan A, Bissinger R, Stockinger K, Lang F: Stimulation of Suicidal Erythrocyte Death by Tafenoquine. Cell Physiol Biochem 2016;39:2464-2476.

-79 Al Mamun Bhuyan A, Signoretto E, Bissinger R, Lang F: Stimulation of Suicidal Erythrocyte Death by Ceritinib-Treatment of Human Erythrocytes. Cell Physiol Biochem 2016;40:1129-1140.

80 Almasry M, Jemaa M, Mischitelli M, Faggio C, Lang F: Stimulation of Suicidal Erythrocyte Death by Phosphatase Inhibitor Calyculin A. Cell Physiol Biochem 2016;40:163-171.

-81 Bissinger R, Artunc F, Qadri SM, Lang F: Reduced Erythrocyte Survival in Uremic Patients Under Hemodialysis or Peritoneal Dialysis. Kidney Blood Press Res 2016;41:966-977.

82 Briglia M, Antonia Rossi M, Faggio C: Eryptosis: Ally or Enemy. Curr Med Chem 2016;

-83 Jemaa M, Mischitelli M, Fezai M, Almasry M, Faggio C, Lang F: Stimulation of Suicidal Erythrocyte Death by the CDC25 Inhibitor NSC-95397. Cell Physiol Biochem 2016;40:597-607.

84 Mischitelli M, Jemaa M, Almasry M, Faggio C, Lang F: Stimulation of Erythrocyte Cell Membrane Scrambling by Quinine. Cell Physiol Biochem 2016;40:657-667.

85 Mischitelli M, Jemaa M, Almasry M, Faggio C, Lang F: Stimulation of Suicidal Erythrocyte Death by Rottlerin. Cell Physiol Biochem 2016;40:558-566.

-86 Mischitelli M, Jemaa M, Almasry M, Faggio C, Lang F: Triggering of Erythrocyte Cell Membrane Scrambling by Emodin. Cell Physiol Biochem 2016;40:91-103.

87 Bester J, Pretorius E: Effects of IL-1beta, IL-6 and IL-8 on erythrocytes, platelets and clot viscoelasticity. Sci Rep 2016;6:32188.

-88 Bissinger R, Kempe-Teufel DS, Honisch S, Qadri SM, Randrianarisoa E, Haring HU, Henes J, Lang F: Stimulated Suicidal Erythrocyte Death in Arteritis. Cell Physiol Biochem 2016;39:1068-1077.

-89 Bissinger R, Lang E, Ghashghaeinia M, Singh Y, Zelenak C, Fehrenbacher B, Honisch S, Chen H, Fakhri H, Umbach AT, Liu G, Rexhepaj R, Liu G, Schaller M, Mack AF, Lupescu A, Birnbaumer L, Lang F, Qadri SM: Blunted apoptosis of erythrocytes in mice deficient in the heterotrimeric G-protein subunit Galphai2. Sci Rep 2016;6:30925.

90 Mischitelli M, Jemaa M, Almasry M, Faggio C, Lang F: Triggering of Suicidal Erythrocyte Death by Fascaplysin. Cell Physiol Biochem 2016;39:1638-1647.

-91 Mischitelli M, Jemaa M, Almasry M, Faggio C, Lang F: Ca2+ Entry, Oxidative Stress, Ceramide and Suicidal Erythrocyte Death Following Diosgenin Treatment. Cell Physiol Biochem 2016;39:1626-1637.

-92 Peter T, Bissinger R, Lang F: Stimulation of Eryptosis by Caspofungin. Cell Physiol Biochem 2016;39:939949.

-93 Pretorius E, du Plooy JN, Bester J: A Comprehensive Review on Eryptosis. Cell Physiol Biochem 2016;39:1977-2000.

-94 Shan F, Yang R, Ji T, Jiao F: Vitamin C Inhibits Aggravated Eryptosis by Hydrogen Peroxide in Glucose-6Phosphated Dehydrogenase Deficiency. Cell Physiol Biochem 2016;39:1453-1462.

95 Xu D, Ran Q, Xiang Y, Linhai J, Smith BM, Bou-Abdallah F, Lund R, Li Z, Dong H: Toward Hemocompatible Self-assembling Antimicrobial Nanofibers: Understanding the Synergistic Effect of Supramolecular Structure and PEGylation on Hemocompatibility. RSC Adv 2016;6:15911-15919.

-96 Zierle J, Bissinger R, Lang F: Inhibition by Teriflunomide of Erythrocyte Cell Membrane Scrambling Following Energy Depletion, Oxidative Stress and Ionomycin. Cell Physiol Biochem 2016;39:1877-1890.

$\$ 97$ Al Mamun Bhuyan A, Signoretto E, Bissinger R, Lang F: Enhanced Eryptosis Following Exposure to Dolutegravir. Cell Physiol Biochem 2016;39:639-650. 


\section{Cellular Physiology Cell Physiol Biochem 2018;51:1996-2009 \begin{tabular}{l|l|l} 
and BOI: 10.1159/000495777 & $\begin{array}{l}\text { (c) 2018 The Author(s). Published by S. Karger AG, Basel } \\
\text { www.karger.com/cpb }\end{array}$
\end{tabular}}

Bhuyan et al.: Inhibition of Eryptosis by Alectinib

\$9 Al Mamun Bhuyan A, Signoretto E, Lang F: Triggering of Suicidal Erythrocyte Death by Psammaplin A. Cell Physiol Biochem 2016;39:908-918.

99 Chang AL, Hoehn RS, Jernigan P, Cox D, Schreiber M, Pritts TA: Previous Cryopreservation Alters the Natural History of the Red Blood Cell Storage Lesion. Shock 2016;46:89-95.

100 Farag MR, Alagawany M, Tufarelli V: In vitro antioxidant activities of resveratrol, cinnamaldehyde and their synergistic effect against cyadox-induced cytotoxicity in rabbit erythrocytes. Drug Chem Toxicol 2017;40:196-205.

101 Ghashghaeinia M, Giustarini D, Koralkova P, Koberle M, Alzoubi K, Bissinger R, Hosseinzadeh Z, Dreischer P, Bernhardt I, Lang F, Toulany M, Wieder T, Mojzikova R, Rossi R, Mrowietz U: Pharmacological targeting of glucose-6-phosphate dehydrogenase in human erythrocytes by Bay 11-7082, parthenolide and dimethyl fumarate. Sci Rep 2016;6:28754.

102 Hortle E, Nijagal B, Bauer DC, Jensen LM, Ahn SB, Cockburn IA, Lampkin S, Tull D, McConville MJ, McMorran BJ, Foote SJ, Burgio G: Adenosine monophosphate deaminase 3 activation shortens erythrocyte half-life and provides malaria resistance in mice. Blood 2016;128:1290-1301.

103 Lang E, Pozdeev VI, Xu HC, Shinde PV, Behnke K, Hamdam JM, Lehnert E, Scharf RE, Lang F, Haussinger D, Lang KS, Lang PA: Storage of Erythrocytes Induces Suicidal Erythrocyte Death. Cell Physiol Biochem 2016;39:668-676.

104 Peter T, Bissinger R, Signoretto E, Mack AF, Lang F: Micafungin-Induced Suicidal Erythrocyte Death. Cell Physiol Biochem 2016;39:584-595.

105 Pretorius E, Bester J, Kell DB: A Bacterial Component to Alzheimer's-Type Dementia Seen via a Systems Biology Approach that Links Iron Dysregulation and Inflammagen Shedding to Disease. J Alzheimers Dis 2016;53:1237-1256.

106 Signoretto E, Laufer SA, Lang F: Stimulating Effect of Sclareol on Suicidal Death of Human Erythrocytes. Cell Physiol Biochem 2016;39:554-564.

107 Bissinger R, Al Mamun Bhuyan A, Signoretto E, Lang F: Stimulating Effect of Elvitegravir on Suicidal Erythrocyte Death. Cell Physiol Biochem 2016;38:1111-1120.

108 Bissinger R, Schumacher C, Qadri SM, Honisch S, Malik A, Gotz F, Kopp HG, Lang F: Enhanced eryptosis contributes to anemia in lung cancer patients. Oncotarget 2016;7:14002-14014.

109 Bonan NB, Steiner TM, Kuntsevich V, Virzi GM, Azevedo M, Nakao LS, Barreto FC, Ronco C, Thijssen S, Kotanko P, Pecoits-Filho R, Moreno-Amaral AN: Uremic Toxicity-Induced Eryptosis and Monocyte Modulation: The Erythrophagocytosis as a Novel Pathway to Renal Anemia. Blood Purif 2016;41:317-323.

110 Egler J, Zierle J, Lang F: Stimulating Effect of Manumycin A on Suicidal Erythrocyte Death. Cell Physiol Biochem 2016;38:1147-1156.

111 Lang E, Pozdeev VI, Gatidis S, Qadri SM, Haussinger D, Kubitz R, Herebian D, Mayatepek E, Lang F, Lang KS, Lang PA: Bile Acid-Induced Suicidal Erythrocyte Death. Cell Physiol Biochem 2016;38:1500-1509.

-112 Larsson A, Hult A, Nilsson A, Olsson M, Oldenborg PA: Red blood cells with elevated cytoplasmic Ca(2+) are primarily taken up by splenic marginal zone macrophages and CD207+ dendritic cells. Transfusion 2016;56:1834-1844.

113 Macczak A, Cyrkler M, Bukowska B, Michalowicz J: Eryptosis-inducing activity of bisphenol A and its analogs in human red blood cells (in vitro study). J Hazard Mater 2016;307:328-335.

114 Officioso A, Alzoubi K, Lang F, Manna C: Hydroxytyrosol inhibits phosphatidylserine exposure and suicidal death induced by mercury in human erythrocytes: Possible involvement of the glutathione pathway. Food Chem Toxicol 2016;89:47-53.

115 Officioso A, Manna C, Alzoubi K, Lang F: Bromfenvinphos induced suicidal death of human erythrocytes. Pestic Biochem Physiol 2016;126:58-63.

116 Peter T, Bissinger R, Liu G, Lang F: Anidulafungin-Induced Suicidal Erythrocyte Death. Cell Physiol Biochem 2016;38:2272-2284.

117 Qadri SM, Donkor DA, Bhakta V, Eltringham-Smith LJ, Dwivedi DJ, Moore JC, Pepler L, Ivetic N, Nazi I, FoxRobichaud AE, Liaw PC, Sheffield WP: Phosphatidylserine externalization and procoagulant activation of erythrocytes induced by Pseudomonas aeruginosa virulence factor pyocyanin. J Cell Mol Med 2016;20:710720.

118 Rohrig G: Anemia in the frail, elderly patient. Clin Interv Aging 2016;11:319-326.

119 Signoretto E, Bissinger R, Castagna M, Lang F: Stimulation of Eryptosis by Combretastatin A4 Phosphate Disodium (CA4P). Cell Physiol Biochem 2016;38:969-981. 


\section{Cellular Physiology Cell Physiol Biochem 2018;51:1996-2009 \begin{tabular}{ll|l} 
and Biochemistry Published onlIne: 6 December 2018 & $\begin{array}{l}\text { ○ 2018 The Author(s). Published by S. Karger AG, Basel } \\
\text { www.karger.com/cpb }\end{array}$ \\
\hline
\end{tabular}}

120 Signoretto E, Castagna M, Al Mamun Bhuyan A, Lang F: Stimulating Effect of Terfenadine on Erythrocyte Cell Membrane Scrambling. Cell Physiol Biochem 2016;38:1425-1434.

121 Signoretto E, Castagna M, Lang F: Stimulation of Eryptosis, the Suicidal Erythrocyte Death by Piceatannol. Cell Physiol Biochem 2016;38:2300-2310.

122 Signoretto E, Honisch S, Briglia M, Faggio C, Castagna M, Lang F: Nocodazole Induced Suicidal Death of Human Erythrocytes. Cell Physiol Biochem 2016;38:379-392.

123 Signoretto E, Zierle J, Bhuyan AA, Castagna M, Lang F: Ceranib-2-induced suicidal erythrocyte death. Cell Biochem Funct 2016;34:359-366.

124 Signoretto E, Zierle J, Bissinger R, Castagna M, Bossi E, Lang F: Triggering of Suicidal Erythrocyte Death by Pazopanib. Cell Physiol Biochem 2016;38:926-938.

125 Waibel S, Bissinger R, Bouguerra G, Abbes S, Lang F: Ritonavir-Induced Suicidal Death of Human Erythrocytes. Basic Clin Pharmacol Toxicol 2016;119:51-57.

126 Wesseling MC, Wagner-Britz L, Huppert H, Hanf B, Hertz L, Nguyen DB, Bernhardt I: Phosphatidylserine Exposure in Human Red Blood Cells Depending on Cell Age. Cell Physiol Biochem 2016;38:1376-1390.

127 Zierle J, Bissinger R, Bouguerra G, Abbes S, Lang F: Triggering of Suicidal Erythrocyte Death by Regorafenib. Cell Physiol Biochem 2016;38:160-172.

128 Abed M, Towhid ST, Mia S, Pakladok T, Alesutan I, Borst O, Gawaz M, Gulbins E, Lang F: Sphingomyelinaseinduced adhesion of eryptotic erythrocytes to endothelial cells. Am J Physiol Cell Physiol 2012;303:C991999.

129 Lang E, Bissinger R, Fajol A, Salker MS, Singh Y, Zelenak C, Ghashghaeinia M, Gu S, Jilani K, Lupescu A, Reyskens KM, Ackermann TF, Foller M, Schleicher E, Sheffield WP, Arthur JS, Lang F, Qadri SM: Accelerated apoptotic death and in vivo turnover of erythrocytes in mice lacking functional mitogen- and stressactivated kinase MSK1/2. Sci Rep 2015;5:17316.

130 Abed M, Feger M, Alzoubi K, Pakladok T, Frauenfeld L, Geiger C, Towhid ST, Lang F: Sensitization of erythrocytes to suicidal erythrocyte death following water deprivation. Kidney Blood Press Res 2013;37:567-578.

131 Voelkl J, Alzoubi K, Mamar AK, Ahmed MS, Abed M, Lang F: Stimulation of suicidal erythrocyte death by increased extracellular phosphate concentrations. Kidney Blood Press Res 2013;38:42-51.

132 Lang E, Jilani K, Bissinger R, Rexhepaj R, Zelenak C, Lupescu A, Lang F, Qadri SM: Vitamin D-Rich Diet in Mice Modulates Erythrocyte Survival. Kidney Blood Press Res 2015;40:403-412.

133 Abed M, Artunc F, Alzoubi K, Honisch S, Baumann D, Foller M, Lang F: Suicidal erythrocyte death in endstage renal disease. J Mol Med (Berl) 2014;92:871-879.

134 Ahmed MS, Langer H, Abed M, Voelkl J, Lang F: The uremic toxin acrolein promotes suicidal erythrocyte death. Kidney Blood Press Res 2013;37:158-167.

135 Polak-Jonkisz D, Purzyc L: Ca(2+) influx versus efflux during eryptosis in uremic erythrocytes. Blood Purif 2012;34:209-210; author reply 210.

136 Calderon-Salinas JV, Munoz-Reyes EG, Guerrero-Romero JF, Rodriguez-Moran M, Bracho-Riquelme RL, Carrera-Gracia MA, Quintanar-Escorza MA: Eryptosis and oxidative damage in type 2 diabetic mellitus patients with chronic kidney disease. Mol Cell Biochem 2011;357:171-179.

137 Bonomini M, Sirolli V, Settefrati N, Dottori S, Di Liberato L, Arduini A: Increased erythrocyte phosphatidylserine exposure in chronic renal failure. J Am Soc Nephrol 1999;10:1982-1990.

138 Lang PA, Beringer O, Nicolay JP, Amon O, Kempe DS, Hermle T, Attanasio P, Akel A, Schafer R, Friedrich B, Risler T, Baur M, Olbricht CJ, Zimmerhackl LB, Zipfel PF, Wieder T, Lang F: Suicidal death of erythrocytes in recurrent hemolytic uremic syndrome. J Mol Med (Berl) 2006;84:378-388.

139 Nicolay JP, Schneider J, Niemoeller OM, Artunc F, Portero-Otin M, Haik G, Jr., Thornalley PJ, Schleicher E, Wieder T, Lang F: Stimulation of suicidal erythrocyte death by methylglyoxal. Cell Physiol Biochem 2006;18:223-232.

140 Lang E, Gatidis S, Freise NF, Bock H, Kubitz R, Lauermann C, Orth HM, Klindt C, Schuier M, Keitel V, Reich M, Liu G, Schmidt S, Xu HC, Qadri SM, Herebian D, Pandyra AA, Mayatepek E, Gulbins E, Lang F, Haussinger D, Lang KS, Foller M, Lang PA: Conjugated bilirubin triggers anemia by inducing erythrocyte death. Hepatology 2015;61:275-284.

141 Qadri SM, Mahmud H, Lang E, Gu S, Bobbala D, Zelenak C, Jilani K, Siegfried A, Foller M, Lang F: Enhanced suicidal erythrocyte death in mice carrying a loss-of-function mutation of the adenomatous polyposis coli gene. J Cell Mol Med 2012;16:1085-1093. 


\section{Cellular Physiology Cell Physiol Biochem 2018;51:1996-2009 \begin{tabular}{ll|l} 
and Biochemistry & DOl: 10.1159/000495777 \\
Published online: 6 December 2018 & $\begin{array}{l}\text { () } 2018 \text { The Author(s). Published by S. Karger AG, Basel } \\
\text { www.karger.com/cpb }\end{array}$ \\
\hline
\end{tabular}}

Bhuyan et al.: Inhibition of Eryptosis by Alectinib

142 Lang PA, Schenck M, Nicolay JP, Becker JU, Kempe DS, Lupescu A, Koka S, Eisele K, Klarl BA, Rubben H, Schmid KW, Mann K, Hildenbrand S, Hefter H, Huber SM, Wieder T, Erhardt A, Haussinger D, Gulbins E, Lang F: Liver cell death and anemia in Wilson disease involve acid sphingomyelinase and ceramide. Nat Med 2007;13:164-170.

143 Borst O, Abed M, Alesutan I, Towhid ST, Qadri SM, Foller M, Gawaz M, Lang F: Dynamic adhesion of eryptotic erythrocytes to endothelial cells via CXCL16/SR-PSOX. Am J Physiol Cell Physiol 2012;302:C644-C651.

144 Andrews DA, Low PS: Role of red blood cells in thrombosis. Curr Opin Hematol 1999;6:76-82.

145 Chung SM, Bae ON, Lim KM, Noh JY, Lee MY, Jung YS, Chung JH: Lysophosphatidic acid induces thrombogenic activity through phosphatidylserine exposure and procoagulant microvesicle generation in human erythrocytes. Arterioscler Thromb Vasc Biol 2007;27:414-421.

146 Zwaal RF, Comfurius P, Bevers EM: Surface exposure of phosphatidylserine in pathological cells. Cell Mol Life Sci 2005;62:971-988.

147 Closse C, Dachary-Prigent J, Boisseau MR: Phosphatidylserine-related adhesion of human erythrocytes to vascular endothelium. Br J Haematol 1999;107:300-302.

148 Gallagher PG, Chang SH, Rettig MP, Neely JE, Hillery CA, Smith BD, Low PS: Altered erythrocyte endothelial adherence and membrane phospholipid asymmetry in hereditary hydrocytosis. Blood 2003;101:46254627.

149 Pandolfi A, Di Pietro N, Sirolli V, Giardinelli A, Di Silvestre S, Amoroso L, Di Tomo P, Capani F, Consoli A, Bonomini M: Mechanisms of uremic erythrocyte-induced adhesion of human monocytes to cultured endothelial cells. J Cell Physiol 2007;213:699-709.

150 Wood BL, Gibson DF, Tait JF: Increased erythrocyte phosphatidylserine exposure in sickle cell disease: flowcytometric measurement and clinical associations. Blood 1996;88:1873-1880.

151 Harrison HE, Bunting H, Ordway NK, Albrink WS: The Pathogenesis of the Renal Injury Produced in the Dog by Hemoglobin or Methemoglobin. J Exp Med 1947;86:339-356. 